\title{
PSYCHOLOGICAL AND SOCIAL DETERMINANTS OF HIV INFECTION: PATH ANALYSIS EVIDENCE FROM JEPARA, CENTRAL JAVA
}

\author{
Ita Fijanah Puspita1), Uki Retno Budihastuti2), Vitri Widyaningsih3) \\ 1)Masters Program in Public Health, Universitas Sebelas Maret \\ 2)Department of Obstetrics and Gynecology, Dr. Moewardi Hospital \\ 3)Faculty of Medicine, Universitas Sebelas Maret
}

\begin{abstract}
Background: HIV/AIDS is a global public health problem. It is a challenge in health discipline and is a very important burden of disease to be addressed. Moreover, it impacts on high mortality. This study aimed to analyze the risk factors of HIV infection. Subjects and Method: This was a case control study conducted in Jepara, Central Java, from April to May 2019. A sample of 200 study subjects was selected by fixed disease sampling. The dependent variable was HIV infection. The independent variables were age, gender, sexual orientation, unsafe sex behavior, frequency of intercourse, injection drug abuse, perceived susceptibility, perceived seriousness, perceived threat, self-efficacy, social capital, and geographical location. The data were obtained from the medical record and questionnaire. The data were analyzed by path analysis.

Results: HIV infection was directly associated with sexual intercourse $(b=1.23 ; 95 \%$ $\mathrm{CI}=0.27$ to $2.19 ; \mathrm{p}=0.012)$, injecting drug use $(\mathrm{b}=2.19 ; 95 \% \mathrm{CI}=0.01$ to $4.37 ; \mathrm{p}=$ o.049), unsafe sex behavior ( $\mathrm{b}=3.10 ; 95 \% \mathrm{CI}=2.21$ to $3.99 ; \mathrm{p}<0.001)$, and sexual orientation $(b=3.69 ; 95 \% \mathrm{CI}=1.35$ to $6.04 ; \mathrm{p}=0.002)$. HIV infection was indirectly associated with age, perceived threat, gender, geographical location, perceived susceptibility, perceived seriousness, self-efficacy, and social capital.

Conclusions: HIV infection is directly associated with sexual intercourse, injecting drug use, unsafe sex behavior, and sexual orientation. HIV infection is indirectly associated with age, perceived threat, gender, geographical location, perceived susceptibility, perceived seriousness, self-efficacy, and social capital.
\end{abstract}

Keywords: HIV/AIDS, sexual behavior, social capital, path analysis

Correspondence:

Ita Fijanah Puspita, Masters Program in Public Health, Universitas Sebelas Maret. Jl. Ir. Sutami 36A, Surakarta 57126, Central Java. Email: itapuspita713@gmail.com. Mobile: 081347970482.

The $6^{\text {th }}$ International Conference on Public Health Best Western Premier Hotel, Solo, Indonesia, October 23-24, 2019 | 65 https://doi.org/10.26911/the6thicph.01.42 